\title{
CXCVII. THE VITAMIN $A_{1}$ AND $A_{2}$ CONTENTS OF MAMMALIAN AND OTHER ANIMAL LIVERS
}

\author{
By ALBERT EDWARD GILLAM \\ From the Chemistry Department, Manchester University
}

(Received 21 July 1938)

THE liver fats of animals in general rank amongst the richest sources of the growth-promoting and anti-xerophthalmic substance known as vitamin A which, in addition to its biological activity, is characterized by an ultra-violet absorption band near $328 \mathrm{~m} \mu$ and by the blue colour that it gives with antimony trichloride in chloroform (main absorption maximum at $620 \mathrm{~m} \mu$ ). These properties of the vitamin are shown with slight modification by the liver fats both of marine fish and of mammals. When, however, the first preparations of really potent concentrates of the vitamin were obtained [Karrer et al. 1931; Heilbron et al. 1932] they were obviously heterogeneous, notably because they contained small but variable quantities of a substance exhibiting an absorption band at $693 \mathrm{~m} \mu$ in the $\mathrm{SbCl}_{3}$ blue colour [Heilbron et al. 1932]. It has since been observed that the liver fats of certain Russian freshwater fish contain more of the $693 \mathrm{~m} \mu$ chromogen than of the more common one characterized by a $620 \mathrm{~m} \mu$ band [Lederer \& Rosanova, 1937] and more detailed spectrophotometric examinations of the liver oils of a variety of freshwater fish [Lederer et al. 1937; Edisbury et al. 1937; Gillam et al. 1938; Edisbury et al. 1938] have confirmed this. The same investigations have also shown that the ultra-violet absorption spectra of the oils are characterized by two maxima near 280 and $350 \mathrm{~m} \mu$, respectively, instead of the single maximum at $328 \mathrm{~m} \mu$ common to the liver oils of marine fish.

It has been suggested that the $693 \mathrm{~m} \mu$ chromogen might be a second vitamin $\mathrm{A}$, possibly specific to freshwater fish [Lederer et al. 1937], whilst Edisbury et al. have tentatively named it vitamin $A_{2}$ [1937] and later "factor $A_{2}$ " [1938]. Although in our earlier concentration of the substance it was not found possible to separate it completely from vitamin $A_{1}$ the results of feeding experiments on rats [Gillam et al. 1938] indicate that it actually possesses the biological activity always associated with vitamin $A_{1}$, whilst the chemical evidence suggests that it is probably a higher isologue $\left(\mathrm{C}_{22} \mathrm{H}_{32} \mathrm{O}\right)$ of this vitamin which, itself, has been shown to have the formula $\mathrm{C}_{20} \mathrm{H}_{30} \mathrm{O}$ [Karrer et al. 1931; Heilbron et al. 1932]. More recent experiments with the physiologically potent concentrate previously examined have shown that it contains another chromogen $(645-650 \mathrm{~m} \mu)$ the presence of which makes the $620 \mathrm{~m} \mu$ chromogen value too high [Lederer, 1938]. On the assumption that this chromogen has no vitamin A activity itself, Lederer [1938] draws the conclusion that more of the total activity of the concentrate must be due to the $693 \mathrm{~m} \mu$ chromogen than was previously supposed. This further justifies the title vitamin $A_{2}$, as also does the fact found by Wald [1937, 1, 2] that the $693 \mathrm{~m} \mu$ chromogen can replace vitamin $A_{1}$ in the visual cycle that occurs in the retinae of freshwater fish.

The generalization that is beginning to emerge from these results is that whereas marine fish liver oils contain the $620 \mathrm{~m} \mu$ chromogen (vitamin $A$ or $A_{1}$ ) with only traces of the $693 \mathrm{~m} \mu$ chromogen (vitamin $\mathrm{A}_{2}$ ), ${ }^{1}$ freshwater fish liver oils 
tend to contain more vitamin $A_{2}$ than vitamin $A_{1}$, or at least a larger proportion of vitamin $A_{2}$ than do the marine fish liver oils. The only mammals that have been examined for vitamin $A_{2}$, namely, the rabbit [Edisbury et al. 1938] and the whale (private communication from Dr R. A. Morton), apparently contain none of this substance.

The present paper records the results obtained by the examination of the livers of a series of animals and birds with particular reference to the total vitamin $A$ content of the liver and the presence or absence of vitamin $A_{2}$.

\section{EXPERIMENTAL}

The procedure adopted in all cases was, firstly, hot saponification of the fresh liver with $\mathrm{KOH}(2 \mathrm{ml} .10 \% \mathrm{KOH}$ in $50 \%$ aqueous alcohol per g. of fresh liver: time of saponification 1-3 hr.) until the tissue was completely broken down. After cooling, the mixture was diluted with water and extracted with ether, the resulting extract being washed with water, dried over anhydrous $\mathrm{Na}_{2} \mathrm{SO}_{4}$ and evaporated to dryness in $\mathrm{N}_{2}$. Part of the unsaponifiable matter so obtained was treated with $\mathrm{SbCl}_{3}$ in chloroform, the blue colour being examined spectroscopically by methods already described [Heilbron et al. 1931]. Values for the relative amounts of vitamins $A_{1}$ and $A_{2}$ present were obtained from the ratio of the intensities of the absorption bands at 620 and $693 \mathrm{~m} \mu$, respectively, of the blue solution. The remaining unsaponifiable matter in chloroform was diluted 1020 times with alcohol and its ultra-violet absorption spectrum determined photographically, using a Hilger E3 quartz spectrograph. The vitamin A content was taken as the mean of the two values obtained from the intensity of absorption of the alcoholic and chloroformic $\mathrm{SbCl}_{3}$ solutions, respectively, on the provisional

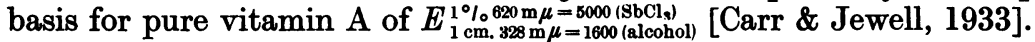

The results are recorded in Table $I$.

\section{Discussion}

Consideration of the data and of previous work [cf. Kuhn, 1933] leads to the conclusion that in marine fish in general (or possibly in some of the animals on which they feed) carotene is ingested (either directly or indirectly from the phytoplankton) and the $\mathrm{C}_{40} \mathrm{H}_{56}$ molecule is broken down into $\mathrm{C}_{20}$ fragments constituting the typical vitamin $\mathrm{A}$. The small amount of vitamin $\mathrm{A}_{2}$ normally present would appear either to be produced as a by-product of this process in the fish themselves, or to be received by them preformed to this small extent from the lower animals on which they feed. On the other hand, freshwater fish (or again some lower organisms eaten by them) must be able, in addition, to break down the carotene molecule into $\mathrm{C}_{22}$ and $\mathrm{C}_{18}$ fragments, the $\mathrm{C}_{22}$ fragment, at least, appearing in the liver in greater concentration than is normally met with in marine fish livers.

The complete absence of vitamin $\mathrm{A}_{2}$ from the livers of the majority of both the individuals and the species of mammals and birds examined indicates that

1 Karrer has suggested the name "Axerophthol" for the classical vitamin A and the class name "Axerophthols" for the higher isologues [Euler et al. 1938]. Using Karrer's nomenclature, the particular axerophthol $\left(\mathrm{C}_{22} \mathrm{H}_{32} \mathrm{O}\right)$ which our earlier experiments indicate as the $693 \mathrm{~m} \mu$ chromogen would be called $\beta$-apo-5-carotinol. Karrer and his collaborators have prepared what they believe to be this compound and whilst it gives a blue colour with $\mathrm{SbCl}_{3}$ the position of the absorption band that gives rise to the colour is apparently quite different from $693 \mathrm{~m} \mu$. If the formula of the compound is beyond doubt then the formula suggested for the $693 \mathrm{~m} \mu$ chromogen will need modification. 


\section{Table I}

\begin{tabular}{|c|c|c|c|c|c|c|}
\hline Animal & Source, etc. & $\begin{array}{l}\text { Wt. fresh } \\
\text { liver } \\
\text { g. }\end{array}$ & $\begin{array}{c}\text { Estimated } \\
\text { total } \\
\text { vitamin A } \\
\text { mg. }\end{array}$ & $\begin{array}{l}\text { Vitamin A } A \\
\text { mg. per } \\
\text { 100 g. } \\
\text { liver }\end{array}$ & $\begin{array}{l}693 \mathrm{~m} \mu \\
\text { chromogen }\end{array}$ & $\begin{array}{l}\text { Ratio of } \\
\text { intensities } \\
693 / 620 \mathrm{~m} \mu\end{array}$ \\
\hline$\stackrel{\text { Lion }}{\text { Felis leo }}$ & $\begin{array}{l}\text { Zoological Gardens } \\
\text { (20 yr. old) }\end{array}$ & 2000 & 160 & $8 \cdot 0$ & Absent & 0.057 \\
\hline $\begin{array}{l}\text { Gibbon } \\
\quad \text { Hylobates concolor }\end{array}$ & Zoo (6 months old) & 110 & 0.75 & 0.70 & $"$ & Not measurable \\
\hline $\begin{array}{l}\text { Giant monitor } \\
\text { Varanus salvator }\end{array}$ & $Z_{00}$ & $\begin{array}{l}\text { (a) } 200 \\
\text { (b) } 113\end{array}$ & $\begin{array}{r}500 \\
74\end{array}$ & $\begin{array}{r}250 \\
65\end{array}$ & Present & $\underline{0 \cdot 11}$ \\
\hline $\begin{array}{l}\text { Python } \\
\text { Python reticulatus }\end{array}$ & Zoo (very old animal) & 800 & 688 & 86 & Absent & 0.023 \\
\hline $\begin{array}{l}\text { Alligator } \\
\text { Alligator mississippien }\end{array}$ & & 225 & 8.0 & 3.5 & $"$ & $<0.20$ \\
\hline $\begin{array}{l}\text { Rabbit } \\
\text { Lepus cuniculus }\end{array}$ & Wild & $27 \cdot 6$ & $4 \cdot 75$ & $17 \cdot 2$ & " & 0.073 \\
\hline $\begin{array}{l}\text { Rat } \\
\text { Mus decumanus }\end{array}$ & Wild town animal, $\widehat{o}$ & $9 \cdot 2$ & 0.55 & $6 \cdot 0$ & $"$ & 0.031 \\
\hline $\begin{array}{l}\text { Mouse } \\
\text { Mus musculus }\end{array}$ & $\begin{array}{l}\text { Laboratory animals } \\
\text { (a) Av. of } 9 \\
\text { (b) Av. of } 15\end{array}$ & $\begin{array}{l}1 \cdot 63 \\
1 \cdot 14\end{array}$ & $\begin{array}{l}0.013 \\
0.0125\end{array}$ & $\begin{array}{l}1 \cdot 1 \\
1 \cdot 1\end{array}$ & $"$ & Not measurable \\
\hline $\begin{array}{l}\text { Guinea-pig } \\
\text { Cavia porcellus }\end{array}$ & $\begin{array}{l}\text { Laboratory animals } \\
\text { Av. of } 3\end{array}$ & $10 \cdot 4$ & 0.07 & 0.68 & $"$ & 0.076 \\
\hline Dog & & 278 & 3.06 & $1 \cdot 1$ & , & $<0.20$ \\
\hline Cat & & $66 \cdot 5$ & $2 \cdot 4$ & $3 \cdot 6$ & , & 0.033 \\
\hline $0 x$ & & 5235 & 340 & $6 \cdot 5$ & $"$ & 0.052 \\
\hline Cow & & 6075 & 132 & $2 \cdot 17$ & " & 0.082 \\
\hline Lamb & & $\begin{array}{l}\text { (a) } 506 \\
\text { (b) } 280\end{array}$ & $\begin{array}{l}56 \\
51\end{array}$ & $\begin{array}{l}11 \cdot 0 \\
14 \cdot 7\end{array}$ & ", & $\begin{array}{l}0.058 \\
0.063\end{array}$ \\
\hline Pig & & $\begin{array}{l}\text { (a) } 844 \\
\text { (b) } 1060\end{array}$ & $\begin{array}{l}67 \\
10\end{array}$ & $\begin{array}{l}7.94 \\
1.0\end{array}$ & $"$ & 0.044 \\
\hline $\begin{array}{l}\text { Frog } \\
\text { Rana temporaria }\end{array}$ & Local, av. of 6 & $0 \cdot 41$ & $\begin{array}{l}\text { Order of } \\
0.0043\end{array}$ & 1.04 & $"$ & Not significant \\
\hline $\begin{array}{l}\text { White Whale } \\
\text { Beluga leucas }\end{array}$ & & - & - & - & $"$ & 0.066 \\
\hline Hen & Av. of 2 & 28 & 3.4 & $12 \cdot 1$ & , & 0.068 \\
\hline Duck & Av. of 4 & 24 & $2 \cdot 93$ & $12 \cdot 2$ & , & $<0.14$ \\
\hline Turkey & & $\begin{array}{l}\text { (a) } 118 \\
\text { (b) } 128\end{array}$ & $\begin{array}{l}24 \cdot 7 \\
26 \cdot 4\end{array}$ & $\begin{array}{l}21 \cdot 0 \\
20 \cdot 7\end{array}$ & $"$ & $\begin{array}{l}0.044 \\
0.06\end{array}$ \\
\hline Pigeon & $\begin{array}{l}\text { Av. of two young } \\
\text { birds }\end{array}$ & $4 \cdot 2$ & 1.37 & $32 \cdot 5$ & " & $0 \cdot 10$ \\
\hline $\begin{array}{l}\text { Kingfisher } \\
\quad \text { Alcedo ispida }\end{array}$ & $\begin{array}{l}\text { Cheshire } \\
\text { (one young fledge- } \\
\text { ling: found dead) }\end{array}$ & 1.9 & 0.15 & $7 \cdot 7$ & Not detected & - \\
\hline $\begin{array}{l}\text { Seal } \\
\quad \text { Phoca vitulina }\end{array}$ & Russia & - & - & - & Present & 0.20 \\
\hline $\begin{array}{l}\text { Otter } \\
\text { Lutra vulgaris }\end{array}$ & Cumberland & 191 & 90 & 47 & $"$ & 0.22 \\
\hline $\begin{array}{l}\text { Rat (fed on vitamin } A_{2} \\
\text { concentrate) }\end{array}$ & & - & - & - & $"$ & $1 \cdot 40$ \\
\hline
\end{tabular}

they cannot convert carotene directly into vitamin $A_{2}$ for, in the herbivorous animals at least, there can be no doubt that the diet normally contains relatively large quantities of carotene. The question arises, however, whether mammals can actually pass preformed vitamin $\mathrm{A}_{2}$ into the liver when it is taken into the digestive tract. To test this point Dr Lederer very kindly supplied us with extracts of the livers of rats fed on concentrates of vitamin $A_{2}$. Examination of these extracts (cf. Table I) revealed the presence of relatively large quantities of the $693 \mathrm{~m} \mu$ chromogen; in fact the livers of the rats were, chromogenically, very similar to those of freshwater fish. 
Since mammals normally do not appear to manufacture the $693 \mathrm{~m} \mu$ chromogen but can pass it into the liver when it is contained in the food eaten, it was argued that mammals that feed on fish should store some of this substance in their livers. Interesting test cases of this point are provided by the seal, for a liver extract of which we are indebted to Dr Lederer, and the otter, of the liver of which a sample was obtained from Cumberland through the kindness of Dr W. S. M. Grieve. Examination showed that both these livers contained vitamin $A_{2}$ in easily detectable amounts (cf. Table I). On the other hand the only specimen of a bird feeding on freshwater fish that we could obtain (i.e. the kingfisher) was found to have no detectable vitamin $A_{2}$ in its liver ${ }^{1}$ (cf. Table I). Thus of all the mammals examined the only ones having the $693 \mathrm{~m} \mu$ chromogen present in the liver were those known to feed on, or to have fed upon, fish. Of the remaining animals and birds examined the only other having any detectable quantity of this chromogen was the giant monitor in which, however, the proportion of this substance present was very small (cf. Table I).

It is interesting to note that the python and the giant monitor had the largest total weight of vitamin $A_{1}$ per liver of all the species examined; moreover, on the basis of percentage weight of vitamin in the liver, these two species stand alone. The particular python examined was a very old $25 \mathrm{ft}$. specimen and it may be that, as in the case of the halibut where the vitamin content of the liver increases with age, individuals of this species also accumulate vitamin $A$ as they become older. Of the remaining species examined with the exception of the otter the percentage of vitamin A in the liver only varied within relatively narrow limits; thus in 18 species the average was $8.3 \mathrm{mg}$. per $100 \mathrm{~g}$. fresh liver, whilst the limits of variation were of the order 1 to $32 \mathrm{mg}$. per $100 \mathrm{~g}$. When mammals are compared with fishes much larger variations are, however, observed [cf. Edisbury et al. 1938].

In this preliminary survey only a few individuals of each species have been examined but it is probable that if more were examined much wider variations would be found. On the other hand the work of Davies \& Moore [1935] indicates that the level of vitamin $A$ in the liver of the rat usually falls within narrow limits; these workers have shown that when rats are fed with very high dosages of vitamin A the abnormally high resultant value for the vitamin content of the liver rapidly falls to normal as soon as the vitamin intake is reduced.

The differences between freshwater fish, marine fish, mammals and birds in the reaction of their liver extracts towards $\mathrm{SbCl}_{3}$ are summarized in Table II.

Table II. Summarized data on the relative amounts of 693 and $620 m \mu$ chromogens in the livers of fish, animals and birds

\begin{tabular}{|c|c|c|c|c|}
\hline & \multirow{2}{*}{$\begin{array}{c}\text { No. of } \\
\text { species } \\
\text { included* }\end{array}$} & \multicolumn{2}{|c|}{$\begin{array}{l}\text { Ratio of the intensities of } \\
\text { absorption at } 693 / 620 \mathrm{~m} \mu\end{array}$} & \multirow[b]{2}{*}{$693 \mathrm{~m} \mu$ absorption band } \\
\hline & & Range found & Average & \\
\hline $\begin{array}{l}\text { Freshwater fish } \dagger \\
\text { Marine fish } \dagger\end{array}$ & 11 & $\begin{array}{l}0 \cdot 25-2 \cdot 62 \\
0 \cdot 04-0.17\end{array}$ & $\begin{array}{l}1 \cdot 680 \\
0 \cdot 110\end{array}$ & $\begin{array}{l}\text { Usually strongly positive } \\
\text { Normally just detectable }\end{array}$ \\
\hline $\begin{array}{l}\text { Animals (almost } \\
\text { all mammals) }\end{array}$ & 11 & $0 \cdot 03-0.17$ & $0.060 \ddagger$ & Only rarely present \\
\hline Birds & 5 & $0 \cdot 04-0 \cdot 10$ & $0.068 \ddagger$ & Only rarely present \\
\hline
\end{tabular}

* Some of these species have been represented by many specimens, others by only one.

† Cf. Gillam et al. [1938] and Lederer [1938] for some detailed examples.

‡ These values, which might be expected to be zero in the absence of the $693 \mathrm{~m} \mu$ band, probably represent the overlap of the $693 \mathrm{~m} \mu$ band at $620 \mathrm{~m} \mu$.

1 The author is indebted to Miss Legge of the Manchester Museum for this specimen. 


\section{SUMMARY}

Extracts of the livers of a number of species of animals and birds have been examined spectroscopically with particular reference to their contents of vitamins $A_{1}$ and $A_{2}$.

It has been found that, in general, mammal and bird livers contain vitamin $A_{1}$ but no vitamin $A_{2}$. In the 21 species examined the only exceptions found were the giant monitor (considerable vitamin $A_{1}$ and only traces of vitamin $A_{2}$ ) and animals known to feed on fish, i.e. the seal and the otter. A mammalian liver exceptional in that it contained more vitamin $A_{2}$ than vitamin $A_{1}$ was obtained by feeding a rat with a concentrate of freshwater fish liver. It would thus appear that although mammals cannot metabolize vitamin $A_{2}$ they can pass it into the liver if they receive it preformed into their digestive tract.

The vitamin $A_{1}$ contents of all the livers examined fell within the rather narrow limits of 0.7-32 mg. per $100 \mathrm{~g}$. fresh liver (average for 18 species $=8 \cdot 3 \mathrm{mg}$. per 100 g.) with the exception only of the python, giant monitor and otter with values of 86,250 and 47 respectively.

The author is indebted to Prof. I. M. Heilbron for his interest in this work and to Dr J. F. Wilkinson and Mr G. Iles, Curator of the Belle Vue Zoological Gardens, Manchester, for specimens of the livers of certain animals. He also owes thanks to Dr R. W. Fairbrother, Dr T. H. B. Bedford and Dr W. Schlapp of this University for specimens of other animals' livers.

\section{REFERENCES}

Carr \& Jewell (1933). Nature, 131, 92.

Davies \& Moore (1935). Biochem. J. 29, 147.

Edisbury, Morton \& Simpkins (1937). Nature, Lond., 140, 234. - \& Lovern (1938). Biochem. J. 32, 118.

Euler, Karrer \& Solmssen (1938). Helv. chim. Acta, 21, 211.

Gillam, Heilbron, Jones \& Lederer (1938). Biochem. J. 32, 405.

Heilbron, Gillam \& Morton (1931). Biochem. J. 25, 1352.

Heslop, Morton, Webster, Rea \& Drummond (1932). Biochem. J. 26, 1178.

Karrer, Morf \& Schöpp (1931). Helv. chim. Acta, 14, 1431.

Kuhn (1933). Chem. Ind. 11, 981.

Lederer (1938). C.R. Soc. Biol., Paris, 206, 781.

_ \& Rosanova (1937). Biochimia, $2,293$.

—_ Gillam \& Heilbron (1937). Nature, Lond., 140, 233.

Wald $(1937,1)$. Nature, Lond., 139, 1017.

- $(1937,2)$. Nature, Lond., 140, 197. 